\title{
Atmospheric bromoform at Cape Point, South Africa: an initial fixed-point data set on the African continent
}

\author{
Brett Kuyper $^{1, a}$, Carl J. Palmer ${ }^{1,2}$, Casper Labuschagne ${ }^{3}$, and Chris J. C. Reason ${ }^{1}$ \\ ${ }^{1}$ Department of Oceanography, University of Cape Town, Cape Town, South Africa \\ ${ }^{2}$ Applied Centre for Climate and Earth System Science, CSIR, Rosebank, South Africa \\ ${ }^{3}$ South African Weather Service, Stellenbosch, South Africa \\ anow at: Department of Chemistry, University of the Western Cape, Cape Town, South Africa
}

Correspondence: Brett Kuyper (3479857@myuwc.ac.za)

Received: 16 March 2017 - Discussion started: 16 May 2017

Revised: 23 March 2018 - Accepted: 3 April 2018 - Published: 25 April 2018

\begin{abstract}
Bromoform mixing ratios in marine air were measured at Cape Point Global Atmospheric Watch Station, South Africa. This represents the first such bromoform data set recorded at this location. Manual daily measurements were made during a month-long field campaign (austral spring 2011) using a gas chromatograph-electron capture detector (GC-ECD) with a custom-built front end thermal desorption trap. The measured concentrations ranged between 4.4 and $64.6( \pm 22.2 \%)$ ppt with a mean of $24.8 \pm 14.8$ ppt. The highest mixing ratios recorded here occurred at, or shortly after, low tide. The diurnal cycle exhibited a morning and evening maximum with lower concentrations throughout the rest of the day. Initial analysis of the data presented indicates that the local kelp beds were the dominant source of the bromoform reported. A concentration-weighted trajectory analysis of the bromoform measurements suggests that two offshore source areas may exist. These source areas appear to be centred on the Agulhas retroflection and extend from St Helena Bay to the southwest.
\end{abstract}

\section{Introduction}

\subsection{Bromoform in the marine environment}

Bromoform $\left(\mathrm{CHBr}_{3}\right)$ is a brominated methane-like hydrocarbon which is a volatile liquid at room temperature. Bromoform is naturally produced by kelp and phytoplankton in the upper layers of the ocean (Quack and Wallace, 2003). A few anthropogenic sources are known, including water treatment, nuclear power plants (Quack and Suess, 1999), and rice paddies (Redeker et al., 2003); however, these tend to be small on a global scale (Carpenter and Liss, 2000; Quack and Wallace, 2003). It was estimated that globally between $2.2 \times 10^{11}-2.5 \times 10^{12} \mathrm{~g} \mathrm{CHBr}_{3} \mathrm{yr}^{-1}$ (Carpenter and Liss, 2000; Quack and Wallace, 2003) is produced of which only $3.0 \times 10^{10} \mathrm{~g} \mathrm{CHBr}_{3} \mathrm{yr}^{-1}$ is anthropogenic (Gschwend et al., 1985; Allonier et al., 1999; Quack and Wallace, 2003), the rest being from natural sources, including $1.3 \times 10^{11} \mathrm{~g} \mathrm{CHBr}_{3} \mathrm{yr}^{-1}$ from brown algae and 1.7$2.0 \times 10^{11} \mathrm{~g} \mathrm{CHBr}_{3} \mathrm{yr}^{-1}$ from phytoplankton (Manley et al., 1992; Carpenter and Liss, 2000; Quack and Wallace, 2003). Outgassing to the atmosphere constitutes the largest known oceanic loss of bromoform, which is relatively stable to chemical loss pathways (hydrolysis and nucleophilic substitution) in seawater at ambient temperatures (Carpenter and Liss, 2000; Quack and Wallace, 2003; Jones and Carpenter, 2005). The production of bromoform in the oceans forms an important step in the biogeochemical cycling of bromine through the Earth system (Warwick et al., 2006; Hossaini et al., 2010).

The production of bromoform by phytoplankton and kelp has been shown to be stimulated through oxidative stress (Quack and Wallace, 2003; Palmer et al., 2005; Kupper et al., 2008), and a maximum rate has been linked with the photosynthetic cycle (Collén et al., 1994). However, the specific reason for bromoform production in these organisms remains unknown (Moore et al., 1996; Paul and Pohnert, 2011; Kuyper, 2014). Production by kelp is thought to be the dominant natural bromoform source to the marine environment 
(Carpenter and Liss, 2000). Different species of kelp are known to produce bromoform at varying rates (e.g. Nightingale et al., 1995). Laboratory studies have measured significantly higher mixing ratios from kelp, per weight, when compared to phytoplankton (Tokarczyk and Moore, 1994; Moore et al., 1996; Carpenter and Liss, 2000). However, kelp species are coastally constrained, while phytoplankton are able to cover hundreds of square kilometres (Jennings et al., 2001; Kudela et al., 2005). A question remains regarding the dominant contribution to the global bromoform budget.

\subsection{Implications for atmospheric chemistry}

The rate of outgassing to the atmosphere, the gas flux rate, is proportional to the wind speed and the solubility of the gas (Liss and Merlivat, 1986; Wanninkhof, 1992; Nightingale et al., 2000). The majority of the outgassed bromoform remains below the tropopause, with a small amount escaping to the stratosphere (Warwick et al., 2006; Hossaini et al., 2010; Saiz-Lopez et al., 2012). The photolysis of bromoform is the dominant sink once in the atmosphere, which results in an atmospheric lifetime of 2-3 weeks (Carpenter and Liss, 2000; Quack and Wallace, 2003). The photolysis of bromoform releases bromine radicals into the atmosphere. These bromine radicals are an important catalyst in the destruction of ozone in the upper-troposphere and lower-stratospheric region (Warwick et al., 2006; Hossaini et al., 2010). Ozone in this region plays two key functions: in the upper-troposphere (UT) ozone is a potent greenhouse gas, whereas in the lower stratosphere (LS) it forms part of the ozone layer, absorbing incoming UV radiation (Saiz-Lopez et al., 2012). In the UT, bromine radicals, released predominantly from bromoform, are known to catalytically react with ozone. This results in the destruction of the ozone and subsequent loss from the region (Aschmann et al., 2009; Hossaini et al., 2010; SaizLopez et al., 2012). Thus, bromine chemistry could play a significant role in climate change through ozone depletion in the UT (Hossaini et al., 2010; Saiz-Lopez et al., 2012).

Estimates have been made of both the amount of bromoform reaching the upper troposphere and the magnitude of the impact this has on climate change. These estimates are based on poorly constrained source emissions from the global ocean (Warwick et al., 2006; Hossaini et al., 2010). It is estimated that between 1.6 and $3.0 \mathrm{ppt}$ of inorganic bromine is contributed directly from bromoform to the lower stratosphere (Aschmann et al., 2009). The background atmospheric bromoform mixing ratios are estimated to be 1-2 ppt. However, local mixing ratios can be elevated above this. This typically occurs in regions with extensive kelp beds and in areas of strong coastal upwelling (e.g. Quack and Wallace, 2003; Quack et al., 2007a). The skill of atmospheric chemistry models would be greatly enhanced if there was better quantification of the source strength of bromoform and, in turn, its impact on bromine radicals and ozone chemistry in different regions. Such enhancement of modelling capacity would lead to a vastly improved understanding of the roles of the source and product gases in the UT-LS region.

Quantifying the inventories of bromoform emissions is thus critical in better characterizing the oxidative capacity of the atmosphere. This is particularly pertinent in the tropics, where deep convection results in a greater percentage of bromine radicals reaching the UT-LS region (Hossaini et al., 2010; Saiz-Lopez et al., 2012). Understanding the sources in the tropics is therefore of great specific scientific interest (Palmer and Reason, 2009). However, there exists a paucity of measurements of bromoform in the tropics (Palmer and Reason, 2009). Existing data in this region tend to be from transient ship cruises, which only provide a discrete snapshot at the point in space/time that the cruise transects the area of interest. Similarly, no time series of measurements at a fixed point currently exists for a coastal site in southern Africa. The Cape Point Global Atmospheric Watch (GAW) monitoring station provides a point from which to begin addressing this lack of southern African measurements. Furthermore, the Cape Point monitoring station fills a critical Southern Hemisphere latitudinal gap between Cape Matatula, American Samoa $\left(14^{\circ} \mathrm{S}\right)$, and Cape Grim, Tasmania $\left(41^{\circ} \mathrm{S}\right)$ (Brunke and Halliday, 1983).

\subsection{Significance of Cape Point location}

Here we present the first ever bromoform data set recorded at the Cape Point GAW station $\left(34.3^{\circ} \mathrm{S} 18.5^{\circ} \mathrm{E}\right.$, Fig. 1). This station offers a unique location from which to measure bromoform mixing ratios in a subtropical region but is also suitable to sample air from the South Atlantic and Southern Ocean. Wind direction and radon concentration $\left({ }^{222} \mathrm{Rn}\right)$ at Cape Point have been extensively used to classify the arriving air masses (Brunke et al., 2004; Whittlestone et al., 2009). A mixture of air sources have been recorded at Cape Point. Brunke et al. (2004) classify these as follows: $100 \%$ clean marine (baseline, ${ }^{222} \mathrm{Rn}<350 \mathrm{mBq} \mathrm{m}^{-3}$ ) to $100 \%$ continental (with/without anthropogenic influence, ${ }^{222} \mathrm{Rn}>1500 \mathrm{mBq} \mathrm{m}^{-3}$ ) and intermediate (mixture of baseline and continental, $800<{ }^{222} \mathrm{Rn}<1500 \mathrm{mBqm}^{-3}$ ). The subtropical location of Cape Point may make this region a particularly significant source of bromoform to the atmosphere, specifically when considering the potential impact on global ozone budgets. The region lies in close proximity to the tropics, where deep convection is able to rapidly transport the outgassed bromoform into the UT-LS, where bromine initiated catalytic ozone destruction occurs. To quantify the importance of the measurements made at Cape Point to tropical deep convection it is necessary to note how the synoptic conditions change seasonally over South Africa. During summer, approximately $5 \%$ of trajectories from South Africa escape to the Atlantic $\left(10^{\circ} \mathrm{S}\right)$, while $75 \%$ of transport exits to the southeast (Tyson and Preston-Whyte, 2000). Ridging high-pressure systems, present during spring and autumn, increase the transport to the tropical Atlantic to $25 \%$ (Tyson 


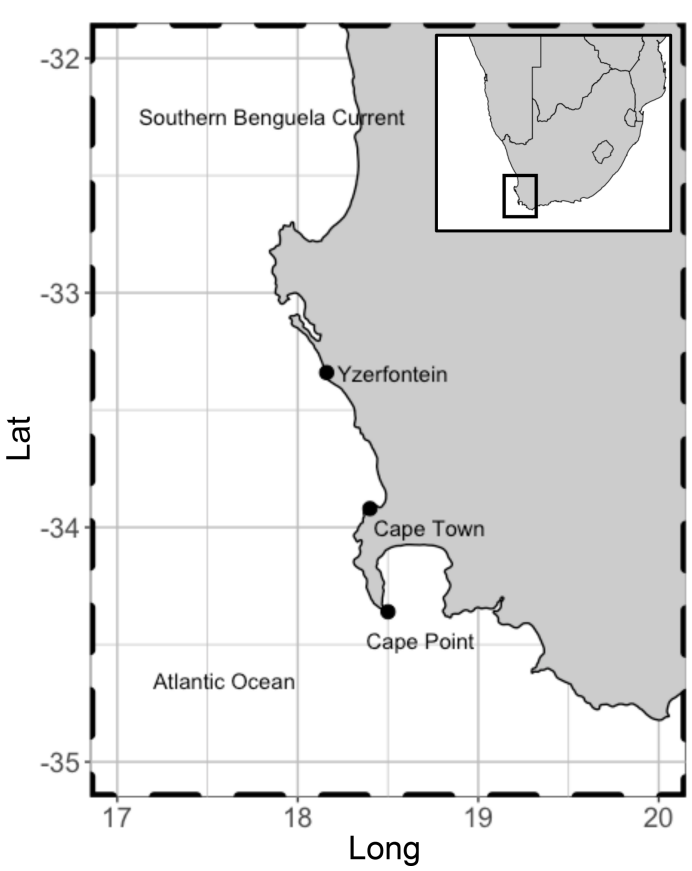

Figure 1. Location of Cape Point in relation to Cape Town. Kelp range along the entire coast. These are dominated by Ecklonia maxima Papenfuss south of Yzerfontein but transition to predominantly Laminaria pallida north of Yzerfontein. Adapted from Kuyper 2014.

and Preston-Whyte, 2000). Moreover, data recorded here are of particular value as the size of the contribution from the Cape Point region is to date largely untested. The Cape Point data presented here represent the first of their kind in Africa or for the South Atlantic region (Cox et al., 2003).

The Southern Ocean is largely regarded as a highly biologically active region, especially during the spring and summer (Arrigo et al., 2012). This region may provide a significant contribution to the global atmospheric loading of bromoform. However, the Southern Ocean is widely under-sampled when it comes to bromoform measurements. Although there have been sporadic ship cruises to the Southern Ocean (Ziska et al., 2013), no long-term work has been done in the Atlantic sector of the Southern Ocean. The data presented here therefore offer the first fixed-point measurements of bromoform in air from the Atlantic sector of the Southern Ocean.

In addition to receiving baseline air from the South Atlantic and Southern Ocean, Cape Point lies in close proximity to extensive kelp beds. The kelp beds extend along the South African coast to the north and east of Cape Point. A variety of remote-sensing techniques have been used to assess the extent and composition of kelp beds in 19 predefined areas along the Cape coast (Anderson et al., 2007). The studies have shown that kelp beds are present in all 19 areas ranging from a minimum of 11 ha coverage in Table Bay to a maximum of just under 1000 ha north towards the Namibia border. The species composition was predominantly Ecklonia max- ima Papenfuss south of Yzerfontein but transitioned to predominantly Laminaria pallida north of Yzerfontein (Fig. 1). Thus, Cape Point is an ideal location to sample the open ocean, local tidally affected kelp beds, as well as the occasional anthropogenic pollution event from the greater Cape Town region, based on the seasonally varying wind direction. Addressing the paucity of data from this region will be instrumental in solving the persistent conundrum as to the major source of bromoform in the atmosphere.

\section{Methods}

The separation, identification, and quantification of bromoform was achieved using a gas chromatograph (GC) with an electron capture detector (ECD) system. This featured a custom-built thermal adsorption-desorption trap for the preconcentration of atmospheric samples and delivery of analytes onto the GC column (Kuyper et al., 2012; Kuyper, 2014). Specific details of the sampling method in this campaign are described below.

\subsection{Sampling}

The measurements of bromoform were made at the Cape Point Global Atmospheric Watch station in the austral spring of October and November 2011. The GAW station sits at the top of a coastal cliff $(230 \mathrm{~m}$ a.s.l $)$ at the end of a peninsula south of Cape Town (Fig. 1). The manual nature of the GC system, coupled with periods of instrument downtime, resulted in a quasi-continuous sampling pattern with a measurement frequency of approximately $45 \mathrm{~min}$ to $1 \mathrm{~h}$. A total of 135 discrete bromoform measurements were made in air samples during this period.

A Shimadzu GC-8A with a Perkin Elmer F-22 ECD was used to record the bromoform concentrations. A J \& W Scientific DB-624 (30 m $\times 320 \times 1.8 \mu \mathrm{m}, 5 \%$ polarity film) capillary column was used in the oven to achieve the separation of samples (Itoh et al., 1997). A $30 \mathrm{~mL} \mathrm{~min}^{-1}$ nitrogen flow was added directly to the ECD in the form of make up gas. Helium (grade 5.0, Air Liquide) at a constant flow rate of $5 \mathrm{~mL} \mathrm{~min}^{-1}$ was maintained through the column at the start of the each analysis. The oven was held at $35^{\circ} \mathrm{C}$ for $5 \mathrm{~min}$ following the injection of a sample. Thereafter, the temperature was increased to $60,90,150$, and $200{ }^{\circ} \mathrm{C}$ every $5 \mathrm{~min}$. The temperature in the oven was increased at $65^{\circ} \mathrm{C} \mathrm{min}-1$ and held isothermally once the new temperature was reached.

Air samples were pre-concentrated in a custom-built thermal desorption unit (TDU, Kuyper et al., 2012). Adsorbents (Carbopac X and Carboxen 1016, $9 \mathrm{mg}$ each) held in a glass tube were cooled to $-20^{\circ} \mathrm{C}$ during the trapping phase. The cooling of the system was achieved by a recirculating chiller filled with glycol. To exclude air from the adsorbent trap a flow of helium $\left(100 \mathrm{~mL} \mathrm{~min}^{-1}\right.$, grade 5.0) was maintained both before and after sampling. Samples were dried using 
magnesium perchlorate, held in a glass moisture trap, before being passed to the trap, as per Groszko and Moore (1998). Air was passed through the adsorbent trap at $100 \mathrm{~mL} \mathrm{~min}^{-1}$ for $15 \mathrm{~min}$, resulting in a $1.5 \mathrm{~L}$ sample volume. The sampling flow rate was checked weekly by means of a digital flow meter. An oil-free piston pump was used to draw air through a $60 \mathrm{~m}$ Decabon sampling line and the adsorbent trap. This was routed through a T-piece with the excess gas vented to the atmosphere. A mass flow controller was used to regulate the gas flow through the adsorbent trap. The pump was operated at $400 \mathrm{~mL} \mathrm{~min}^{-1}$, and a needle valve on the exhaust was used to ensure sufficient pressure in the sampling line for the mass flow controller to operate.

A built-in resistance wire heated the TDU glass tube to $400{ }^{\circ} \mathrm{C}$ to desorb samples for injection. A second-stage cryofocusing system was used at the head of the column, with liquid nitrogen, to improve the chromatography. The liquid nitrogen was held at the head of the column for the duration of the primary injection. Thereafter, boiled water was used to desorb the samples trapped at the head of the column.

\subsection{Calibration}

An external calibration method was used to verify the system performance. A custom-built permeation oven was used to deliver aliquots of bromoform at varying concentrations to the trap (Wevill and Carpenter, 2004; Kuyper, 2014). A bromoform permeation tube held at $70^{\circ} \mathrm{C}$ (permeating at $343 \mathrm{ng} \mathrm{min}^{-1}$ ) was flushed with nitrogen (grade 5.0, Air Liquide) at $100 \mathrm{~mL} \mathrm{~min}^{-1}$. This gas mixture was continually passed through a $100 \mu \mathrm{L}$ sample loop and exhausted through a halocarbon trap. Aliquots of 100-300 $\mu \mathrm{L}$ (one to three sample loops) of the resulting permeation gas (bromoform diluted in nitrogen) were introduced to the thermal desorption unit from the permeation oven. Calibration samples were passed through the drying trap as for air samples; thus, any loss would be consistent for air and calibration methods. The calibration points were analysed using the same temperature programme as air samples to ensure identical retention times. These were also used for the identification of bromoform.

A complete calibration curve (Fig. 2) was measured prior to the start of the experimental period. The peak area was determined from the repeated injection of one to three loops of diluted bromoform in nitrogen gas. Peak areas were calculated through the trapezoid integration method and were computed in MATLAB (Poole, 2003). The mixing ratios of the injected loops were calculated from the number of moles of bromoform injected, as follows. Each loop injection resulted in $0.343 \mathrm{ng}$ of bromoform being loaded on the trap, based on the calibrated rate of the permeation tube (Wevill and Carpenter, 2004; Kuyper, 2014). The number of moles of bromoform on the trap was calculated from this mass which resulted in $1.36 \times 10^{-12} \mathrm{~mol}$ being loaded on the trap, per sample loop injection. The number of molecules of bromoform was calculated by multiplying the number of moles by

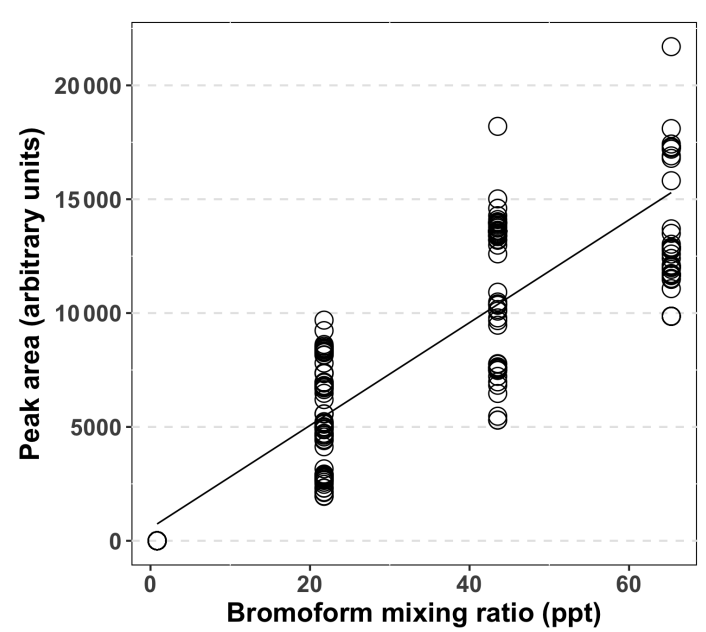

Figure 2. Combined calibration data for the GC-ECD system for bromoform, based on multiple loop injections and interpolation over the entire sampling period. Peak area calculated using the trapezoid method.

the Avogadro constant to yield the number of bromoform molecules on the trap. The total number of molecules in a sample was calculated by multiplying the air number density $\left(2.5 \times 10^{25}\right.$ molecules $\left.\mathrm{m}^{-3}\right)$ with the sample volume $(1.5 \mathrm{~L})$. The bromoform mixing ratio of one loop was calculated as the number of bromoform molecules of one loop as a fraction of number of molecules in a sample multiplied by $10^{12}$ to yield parts per trillion.

A complete system calibration was performed at the start of the sampling at Cape Point (12/13 October 2011). Thereafter, a calibration point of one to three loops was measured approximately daily to account for system drift. After the initial calibration the daily calibration points were coerced into a regular matrix, with $8 \mathrm{~h}$ time steps. This resulted in three calibration points per day. Gaps between calibration points were interpolated using a three-point running mean. An overall $r^{2}$ of 0.82 between the peak area and mixing ratio was achieved using this system during the sampling period (Fig. 2). An analysis of peak area of repeated two-loop injections indicated a system precision of $22.2 \%$ based on the relative standard deviation (RSD), including the running mean estimates. Following an analysis of the calibration curve a limit of detection of $0.21 \mathrm{ppt}$ was determined for this system. An interquartile range (IQR) method was used to search for and remove outlying data within the data set (Underhill and Bradfield, 2005). The IQR is the difference between the 25 and $75 \%$ quartiles. This is then multiplied by 1.5 and either added to or subtracted from the 75 or $25 \%$ quartile, respectively. Any value greater than the upper bound was removed, whereas the lower bound was below the limit of detection (LOD). The upper bound was calculated to be $71.4 \mathrm{ppt}$. 


\subsection{Ancillary measurements: Cape Point, Global Atmospheric Watch}

The GAW station at Cape Point is operated by the South African Weather Service. In addition to the standard meteorological parameters, numerous climate relevant gases are quantitatively measured here, including $\mathrm{CO}_{2}, \mathrm{CH}_{4}, \mathrm{CO}$, radon $\left({ }^{222} \mathrm{Rn}\right.$ ), and $\mathrm{O}_{3}$ (Whittlestone and Zahorowski, 1998; Brunke et al., 2004; Whittlestone et al., 2009).

Air samples were drawn in at the top of a $30 \mathrm{~m}$ high sampling mast. A continuous-flow system was used in the laboratory to exclude the accumulation of any contamination. Sequential cold trapping at -5 and $-40{ }^{\circ} \mathrm{C}$ along the flow path was used to dry air samples prior to measurement. A 30 min mean was applied to all data to standardize different sampling periods.

The ozone measurements were made on a Thermo Electron $49 \mathrm{C}$ analyser. These analysers are based on the UV absorption technique and calibrated every two months. Daily zero and span measurements were used to assess the longterm stability of the detectors. A Trace Analytical RGA3 was used to measure atmospheric $\mathrm{CO}$ mixing ratios. The detector uses a reduction of mercuric oxide $(\mathrm{HgO})$ to determine the concentration of CO (Brunke et al., 2004). A measurement was made every $15 \mathrm{~min}$ with a calibration occurring every $2 \mathrm{~h}$. Radon $\left({ }^{222} \mathrm{Rn}\right)$ measurements were made in an Australian Nuclear Science and Technology Organisation (ANSTO)-build, two-stage $\alpha$-decay system which detects the collected radon daughter products (Whittlestone and Zahorowski, 1998; Whittlestone et al., 2009). A sample was measured half-hourly and calibrated monthly.

\subsection{Ancillary measurements: NOAA HYSPLIT model, marine boundary layer height, and diurnal cycle}

\section{NOAA Hysplit model}

The HYbrid Single-Particle Lagrangian Integrated Trajectory (HYSPLIT: http://www.ready.noaa.gov/) model was used in addition to the chemical tracers to examine the source of air masses being sampled (Stein et al., 2015). These trajectories were generated using the NCEP reanalysis data as the meteorological data in $R$. The back trajectories were calculated for $96 \mathrm{~h}$ prior to bromoform measurement. The trajectories were merged with the bromoform data set to allow for integrated analysis using the "openair" package (Carslaw and Ropkins, 2012). This package comprises a range of statistical tools to examine back trajectories, in order to identify source regions or contributions.

The potential source contribution function (PSCF) in $\mathrm{R}$ openair calculates the probability that a source exists at a specific location (Fleming et al., 2012; Pekney et al., 2006). The PSCF is calculated by the ratio of trajectories with elevated concentrations to the number of times those trajectories pass through a specific point, defined as grid cells. A value for each grid cell is calculated. These grid cell values can be the same when the sample concentrations are either marginally above or greatly elevated from a defined criterion, e.g. the mean (Hsu et al., 2003; Carslaw and Ropkins, 2012). Consequently, the difference between strong and moderate sources can be difficult to distinguish. The concentration-weighted trajectory (CWT) method can be used to potentially identify source areas through the calculation of concentration fields. The mean of the concentration for each grid cell was calculated as follows:

$\ln \left(\bar{C}_{i j}\right)=\frac{1}{\sum_{k=1}^{N} \tau_{i j k}} \sum_{k=1}^{N} \ln \left(c_{k}\right) \tau_{i j k}$,

where $i$ and $j$ are the grid indices, $k$ is the index of the trajectory, $N$ is the total number of trajectories used, $c_{k}$ is the pollution concentration of trajectory $k$ upon arrival, and $\tau_{i j k}$ is the residence time of trajectory $k$ in grid $(i, j)$ (Carslaw and Ropkins, 2012). High concentrations at the measurement site would, on average, be caused by grid cells with elevated values of $\bar{C}_{i j}$, thus indicating possible source regions. The CWT back trajectory calculation was performed on the entire data set of bromoform measurements at Cape Point. As a first approximation of the offshore sources of bromoform to Cape Point a CWT model analysis of the back trajectories was performed.

\section{Marine boundary layer (MBL) height}

Twice daily radiosondes were released from Cape Town international airport at local midnight and noon. The airport lies approximately $60 \mathrm{~km}$ northeast of Cape Point. The height of the MBL was determined by the surface and elevated temperature inversion methods from the radiosonde data (Seibert et al., 2000; Seidel et al., 2010). The calculated boundary layer height at the airport was used as a proxy for the marine boundary layer at Cape Point.

\section{Tidal height}

The tidal height for Cape Town was obtained from the South African Hydrographic Office (SAHO). Tidal gauges are used to measure the height in the harbours around South Africa. Due to periodic instrument failures of some of the gauges around Cape Town during the bromoform sampling period, tidal height estimates were used to interpolate over any gaps. The height is given in metres above a SAHO locally defined chart datum, and therefore, the lower the value the lower the tide.

\section{Diurnal cycle}

A mean diurnal cycle was calculated from the full range of Cape Point measurements using the "timeVariation" function of openair (Carslaw and Ropkins, 2012). The data were 
sorted into 24 hourly bins. The time of the sampling was used to assign an hourly bin to each measurement. The mean and $95 \%$ confidence interval of the mean in each bin were then calculated.

\section{Results and discussion}

The bromoform mixing ratios at Cape Point were measured to be in the range 4.4-64.6 ppt with a mean of $24.8 \pm 14.8 \mathrm{ppt}$ (Fig. 3). Bromoform was typically in the range of 4-20 ppt, but on several occasions elevated mixing ratios were encountered that could last for several hours (Fig. 3). The range of variability observed at Cape Point is comparable to previously published work, specifically with reference to coastal sites (Table 1).

The measurements were made in a variety of air masses ranging from clean marine to continental air. This suggests that a number of sources may have impacted on the bromoform mixing ratios at Cape Point. Nearly $57 \%$ of bromoform measurements recorded here were below the mean. This indicates that the mean value is skewed by a few elevated bromoform mixing ratios. When examined over the whole data set, the bromoform mixing ratios showed only weak correlations with the measured meteorological and physical measurements $\left(r^{2}<0.4\right)$.

\section{Link to tidal cycle}

The full tidal spectrum was captured at Cape Point during the bromoform sampling period, including two neap tides and a spring tide. A maximum tidal range of approximately $2 \mathrm{~m}$ was observed during the spring tide. This range decreased to a maximum of $1 \mathrm{~m}$ during the neap tides (Fig. 3). Exposure of kelp (which as discussed is present in abundance at Cape Point) to the atmosphere at low tide has been linked with an increase in atmospheric bromoform mixing ratios; for example, a site at which this has been observed is Mace Head on the west coast of Ireland (Carpenter et al., 1999). An increase in the oxidative stress on the kelp initiated by solar radiation is thought to drive this correlation (Carpenter et al., 1999; Palmer et al., 2005). However, the measured bromoform mixing ratios reported here do not correlate well with the tidal pattern. While the maximum tidal range in the vertical at Cape Point is comparable to that at Mace Head, the horizontal extent is much smaller. This may explain the lack of local correlation. Consequently, during low tide at Cape Point, only the tops of the kelp fronds become exposed to the atmosphere. This is common around the coast of South Africa. Nonetheless, the elevated bromoform events with the highest mixing ratios appear to mostly occur shortly after low tide (Fig. 3). It is therefore likely that the extensive local kelp beds are an important source of the bromoform observed at the station.

\section{Air mass characterization}

Radon $\left({ }^{222} \mathrm{Rn}\right)$ and CO have been extensively used as tracers for continental and anthropogenic contamination, respectively, in air mass characterization including at Cape Point (Brunke et al., 2004). The measurements of radon $\left({ }^{222} \mathrm{Rn}\right)$ and carbon monoxide $(\mathrm{CO})$, which were generally extremely low, show short elevated periods in the observations (Fig. 3). This indicates that majority of the bromoform measurements made at Cape Point were under clean marine conditions. Of the 1535 half-hourly measurements that make up the meteorological data observed at Cape Point during October/November, $68 \%$ were of clean marine origin. The bromoform mixing ratios in this clean air displayed a mean $23.5 \mathrm{ppt}$ and ranged between 5.12 and $64.6 \mathrm{ppt}$ (Table 2). The variations in ${ }^{222} \mathrm{Rn}$ and $\mathrm{CO}$ concentrations occurred concurrently and mostly when the wind was from a northwesterly direction, which suggests a continental origin and therefore anthropogenic contributions to the chemical composition of the air masses. The continental contaminated air made up $9 \%$ of the total measurements, with intermediate air masses accounting for $7.5 \%$ of the measurements.

The bromoform mixing ratios in intermediate air samples showed a similar mean to that of clean marine air with a mean of $24.3 \mathrm{ppt}$ (Table 2). The introduction of intermediate or continental air at Cape Point potentially allows for the determination of the scale of the anthropogenic contributions in general for this region. Since the intrusion of intermediate air occurs predominantly in winter, a longer time series could test the relative contributions more extensively. In the case presented here, we are not able to conclusively separate anthropogenic and biogenic sources, due to the limited, single-species data set. However, given the small difference in means, the data suggest that an anthropogenic contribution is not significant. The extensive kelp beds present to the north of Cape Town further complicate the matter. An expanded suite of sampled compounds would assist in the separation of sources through the examination of related compounds such as the ratio to $\mathrm{CH}_{2} \mathrm{Br}_{2}$. It has been well documented that the contribution of anthropogenically produced bromoform is generally smaller than from natural processes on a global scale (Quack and Suess, 1999; Quack and Wallace, 2003). While, on a local scale anthropogenic source can dominate (Quack and Suess, 1999), during this sampling period the dominant contribution of bromoform was from the clean marine air masses and, therefore, from biogenic sources (Table 2).

Atmospheric bromoform measurements from Mace Head, Ireland, show periods of elevated mixing ratios (Dickon Young, personal communication, 2017). Analysis of these elevated mixing ratios at Mace Head suggests that the local marshes may be the most likely source. However, the reason why the marshes should be a source of bromoform remains unclear at this time. Although not surrounded by marshes, Cape Point is enclosed by natural vegetation called 


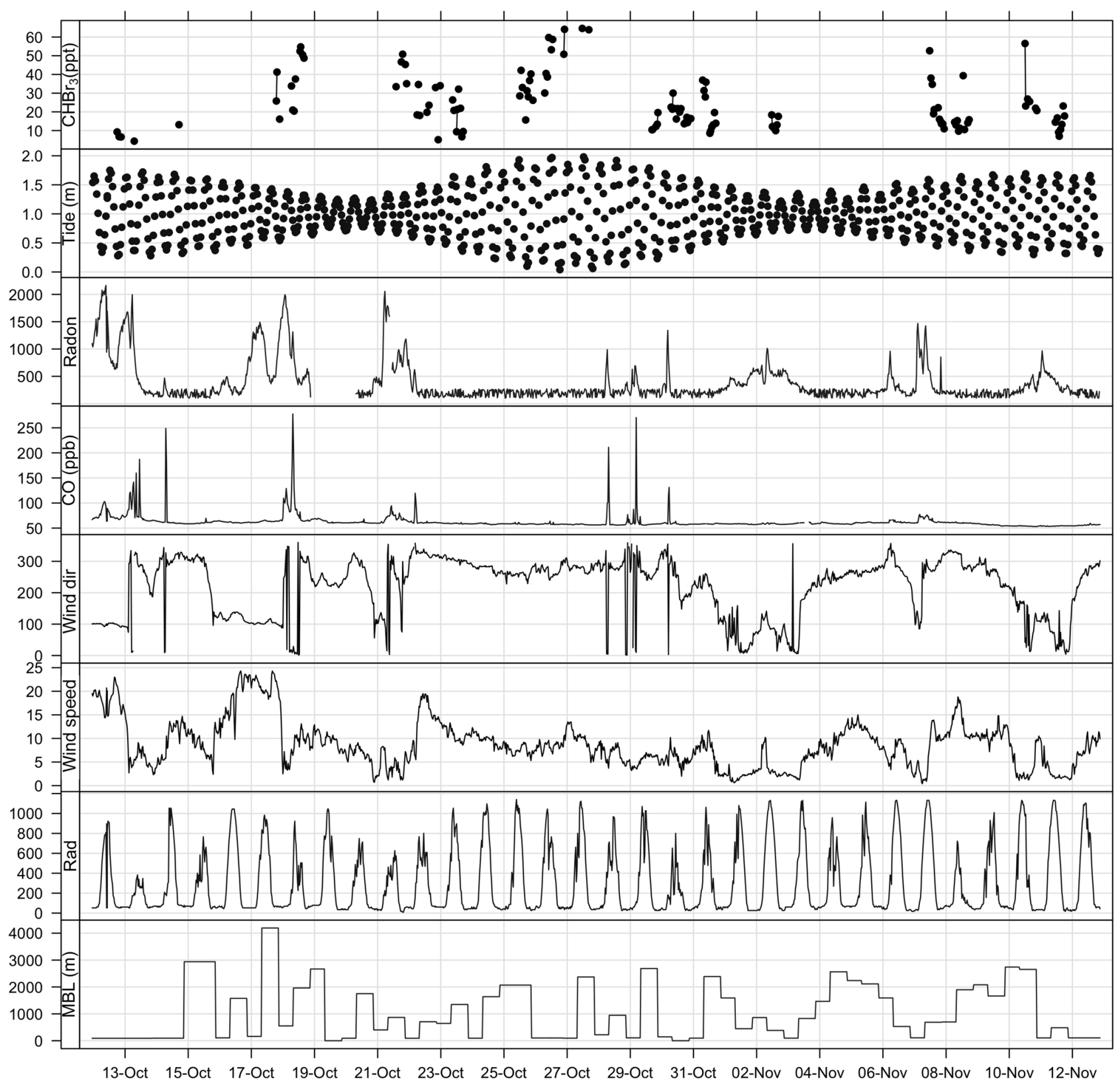

Figure 3. Time series plot of bromoform and meteorological measurements at Cape Point during October/November 2011. Tide height given in metres above SAHO datum, radon in $\mathrm{mBqm}^{-3}$, wind direction in degrees, wind speed in $\mathrm{ms}^{-1}$, and radiation in $\mathrm{W} \mathrm{m}^{-2}$.

fynbos. It is possible that the fynbos releases bromoform into the local atmosphere. This would be particularly pertinent with air masses arriving from the north. A small study has previously examined the bromoform emissions from fynbos when burnt (Kuyper et al., 2012). The measured mixing ratios in this study showed a high degree of variability with a mean of $33.9 \mathrm{ppt}$ and standard deviation of $40 \mathrm{ppt}$. The limited scope and high variability meant that no firm conclusions could be drawn regarding the release of bromoform from the fynbos (Kuyper et al., 2012).

\section{Meteorology}

Wind speed has a complicated relationship with observed bromoform mixing ratios in marine air. The processes of bromoform sea-air flux and atmospheric dilution, both proportional to wind speed, oppose each other in their effect on the atmospheric concentration of bromoform at a given location. At low wind speeds there is a low dilution and bromoform flux into the atmosphere. As the wind speed increases so do the rates of dilution and gas flux. The wind speed observed at Cape Point over this sampling period was dom- 
Table 1. Selected comparison measurements of bromoform in air samples above coastal, upwelling, open-ocean, and lower marine boundary layer regions. Tidal height is given in metres above the standard datum.

\begin{tabular}{|c|c|c|c|c|c|c|c|}
\hline Location & Date & Latitude & \multicolumn{3}{|c|}{$\mathrm{CHBr}_{3}(\mathrm{ppt})$} & Reference & Region \\
\hline New Hampshire & Jun-Aug 2002-2004 & $43.1^{\circ} \mathrm{N}$ & 0.2 & 37.9 & $5.3-6.3$ & Zhou et al. (2008) & Coastal \\
\hline Mauritanian upwelling & Mar-Apr 2005 & $16-21^{\circ} \mathrm{N}$ & 0.1 & 0.6 & 0.2 & Quack et al. (2007b) & Upwelling \\
\hline Cape Verde & May-Jun 2007 & $16.8^{\circ} \mathrm{N}$ & 2.0 & 43.7 & $4.3-13.5$ & O’Brien et al. (2009) & Coastal \\
\hline $\mathrm{R} / \mathrm{V}$ Sonne & July 2014 & $2-16^{\circ} \mathrm{N}$ & 0.79 & 5.07 & 2.08 & Fuhlbrügge et al. (2016a) & Open ocean \\
\hline Atlantic Ocean & Oct-Nov 2002 & $10^{\circ} \mathrm{N}$ & 0.5 & 27.2 & - & Quack et al. (2004) & Open ocean \\
\hline SHIVA & Nov-Dec 2011 & $0-8^{\circ} \mathrm{N}$ & 1.23 & 3.35 & 1.81 & Sala et al. (2014) & MABL WASP \\
\hline Borneo & Apr-Jul 2008 & $4.70^{\circ} \mathrm{N}$ & $2-5$ & 60 & - & Pyle et al. (2011) & Coastal \\
\hline Strait of Malacca & Jun-Jul 2013 & $2-6^{\circ} \mathrm{N}$ & 1.85 & 5.25 & 3.69 & Mohd Nadzir et al. (2014) & Coastal \\
\hline Sulu-Sulawesi & Jun-Jul 2013 & $2-6^{\circ} \mathrm{N}$ & 1.07 & 2.61 & 1.60 & Mohd Nadzir et al. (2014) & Coastal \\
\hline Christmas Island & Jan 2003 & $1.98^{\circ} \mathrm{N}$ & 1.1 & 31.4 & $5.6-23.8$ & Yokouchi et al. (2005) & Coastal \\
\hline Cape Grim & 2003 & $40.7^{\circ} \mathrm{S}$ & 1.3 & 6.4 & 2.9 & Yokouchi et al. (2005) & Coastal \\
\hline Coastal South America & Dec 2007-Jan 2008 & $55^{\circ} \mathrm{S}$ & 1.8 & 11 & 7.4 & Mattsson et al. (2013) & Coastal \\
\hline Antarctic coast & Dec 2007-Jan 2008 & $65^{\circ} \mathrm{S}$ & 2.1 & 4.9 & 3.2 & Mattsson et al. (2013) & Coastal \\
\hline Antarctic Ocean & Dec 2007-Jan 2008 & $65-67^{\circ} \mathrm{S}$ & 1.9 & 3.9 & 2.3 & Mattsson et al. (2013) & Open ocean \\
\hline
\end{tabular}

Table 2. Comparison of bromoform mixing ratios from different air mass sources, sorted by radon concentration.

\begin{tabular}{lrrr}
\hline & Clean marine & Intermediate & Continental \\
\hline${ }^{222} \mathrm{Rn} \mathrm{mBq}^{-3}$ (number) & $<350(1028)$ & $800-1500(115)$ & $>1500(45)$ \\
${ }_{\text {Mean } \mathrm{CHBr}_{3} \text { ppt (number of samples) }}$ & $23.5(91)$ & $24.3(12)$ & $\mathrm{NA}$ \\
Range $\mathrm{CHBr}_{3}$ (ppt) & $5.1-64.6$ & $4.4-46.7$ & $\mathrm{NA}$ \\
\hline
\end{tabular}

inated by lower wind speeds $\left(<10 \mathrm{~m} \mathrm{~s}^{-1}\right)$. The full range extended from calm $\left(<5 \mathrm{~m} \mathrm{~s}^{-1}\right)$ to occasionally gale force $\left(>20 \mathrm{~m} \mathrm{~s}^{-1}\right)$. The elevated wind speeds were associated with transient cold fronts that influence the Cape in winter and spring (Tyson and Preston-Whyte, 2000). The bromoform mixing ratios at Cape Point show a varied response to the observed wind speed; on some occasions at high wind speeds the mixing ratio was also elevated whereas at other times it was not. The lack of direct correlation at this site may be evidence of the complexity and interaction of these processes as described above.

In a coastal upwelling environment it has been shown that the height of the marine boundary layer (MBL) can play a significant role in the observed bromoform mixing ratio. For example, Fuhlbrügge et al. (2013) found that a lower marine boundary layer height acted to concentrate bromoform mixing ratios recently released from the ocean surface. Although a direct relationship between bromoform mixing ratios and MBL height was observed at Cape Point, it is possible that MBL height played a role in the measurements observed.
As the MBL height is elevated the rate of atmospheric dilution increases. This would result in lower measured bromoform mixing ratios. Conversely as the MBL decreases, so the volume of atmosphere into which gases are diluted decreases, resulting in a concentrating effect and increase in measured concentration. The lack of a direct observed relationship could be a result of Cape Point sitting approximately $60 \mathrm{~km}$ from Cape Town international airport where the radiosondes were released. However, the effect of changes in the MBL height may be reflected in the variability of the bromoform measurements.

\subsection{Solar radiation and diurnal cycle}

During the sampling period the solar radiation at Cape Point daily reached a level of $600-1000 \mathrm{~W} \mathrm{~m}^{-2}$ (Fig. 3). While there was no direct correlation between solar radiation and bromoform observed, the highest mixing ratios occurred when the solar radiation was typically above $800 \mathrm{~W} \mathrm{~m}^{-2}$.

The mean Cape Point diurnal cycle of bromoform mixing ratios displayed an increase through the morning from an es- 


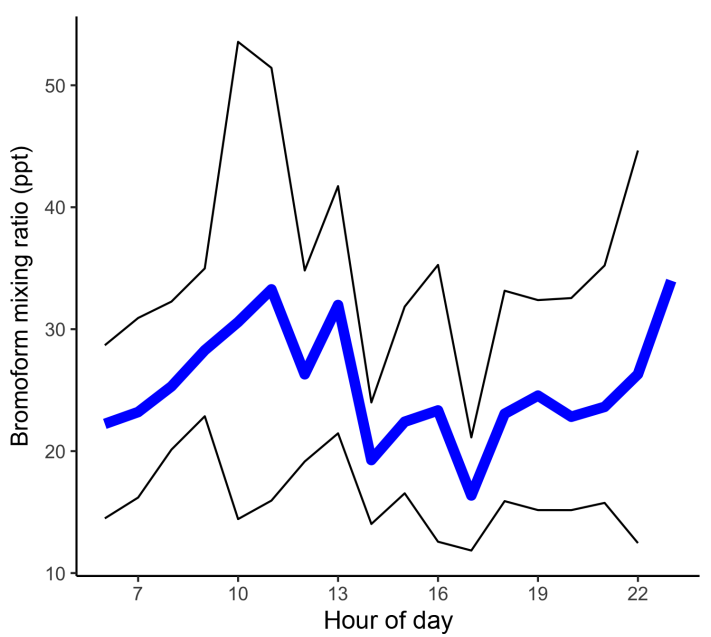

Figure 4. Mean diurnal cycle, calculated from all measurements binned by hour. The black lines above and below signify the $95 \%$ confidence interval.

timated overnight low of $22.2 \mathrm{ppt}$, based on the first measurements of the day, to a mean maximum of $33.3 \mathrm{ppt}$ at 11:00 (Fig. 4). Thereafter, the mixing ratios decreased through the afternoon. A second maximum in the mean mixing ratios was observed in the early evening. This secondary maximum reached a mean mixing ratio of $34.0 \mathrm{ppt}$. There were no measurements taken between midnight and 05:00, and the first morning measurements were taken prior to local sunrise. It is assumed that these measurements, taken before sunrise, were representative of the nighttime conditions.

This pattern in the diurnal mean bromoform mixing ratio measurements at Cape Point is similar to that observed in previously published literature (Ekdahl et al., 1998; Carpenter and Liss, 2000; Abrahamsson et al., 2004). It has been hypothesized that the increase in concentrations observed in the morning is as a result of sunrise. The onset of solar radiation stimulates photochemistry leading to oxidative stress in the kelp cells and the release of bromoform (Collén et al., 1994; Pedersén et al., 1996; Ekdahl et al., 1998) whereas it would appear that, through this mechanism, the maxima of bromoform mixing ratios and solar radiation should coincide (Abrahamsson et al., 2004). As discussed above, changes in the height MBL act to concentrate or dilute the mixing ratio of samples in the lower atmosphere. The atmosphere into which gases can mix increases through the morning as the MBL height rises, thus causing a dilution of trace gas in the atmosphere (Fuhlbrügge et al., 2013). This is most likely reflected in the decrease in bromoform mixing ratios at about noon and the stabilization through the afternoon. A small contribution from the photolysis of bromoform may be present; however, this would be neither detectable nor significant. A decrease in the rate of production in the afternoon or the arrival of air masses from alternate sources might explain the decrease in the late afternoon. A decreasing MBL height in the late af- ternoon or early evening would act to concentrate any locally released bromoform. The literature suggests that bromoform production may also be related to respiration (Ekdahl et al., 1998; Carpenter and Liss, 2000). During respiration, it is theorized that through the haloperoxidase enzyme reactions, excess intracellular hydrogen peroxide $\left(\mathrm{H}_{2} \mathrm{O}_{2}\right)$ is removed and bromoform formed (Collén et al., 1994). Therefore, production into the evening is possible and with a lowered MBL height the measured bromoform might be large. The evening maximum in mixing ratios is, therefore, expected and consistent with previously studies in Gran Canaria and the Southern Ocean (Ekdahl et al., 1998; Abrahamsson et al., 2004).

\subsection{Back trajectory analysis}

Given the relatively long atmospheric lifetime of bromoform (3 weeks), there could be sources offshore that contribute to the observed measurements at Cape Point (Carpenter and Liss, 2000). While not excluding the local source, the contribution of offshore sources was investigated using the openair CWT calculations of back trajectories associated with bromoform mixing ratios. The CWT model suggests a large fetch and variability of source region for air masses arriving at Cape Point, mainly to the southwest (Fig. 5a). This large fetch included large areas of low bromoform entrainment, as would be expected from most of the open ocean, and trajectories of high entrainment. The model output suggests a number of trajectories with elevated mixing ratios. There are both offshore and inshore trajectories (Fig. 5a and b). There appears to be region to the southwest of Cape Town that generates elevated mixing ratios. Furthermore, the area directly to the south of Cape Point exhibits the highest $\bar{C}_{i j}$ values and appears to be centred over the Agulhas retroflection region (Beal et al., 2011).

The Agulhas retroflection region is an area in which the highly productive cold waters of the southern Benguela meet the warmer water from the Agulhas current. This combination of productive waters (with potentially high $\mathrm{CHBr}_{3}$ ) and warmer sea surface temperatures driving higher rates of sea-air fluxes, could represent ideal conditions for observing higher atmospheric bromoform mixing ratios.

The region to the southwest of South Africa extends from the coast to $45^{\circ} \mathrm{S}$ and appears to contain numerous trajectories of elevated bromoform mixing ratios. It is possible that certainly the outer areas of this region are warm core rings that have been shed off the Agulhas current. The elevated area at the coast of South Africa occurs over Cape Columbine $\left(33^{\circ} \mathrm{S}\right)$ into St Helena Bay (Fig. 5b). This area appears to be centred over St Helena Bay, an area known for strong coastal upwelling (Jennings et al., 2001; Kudela et al., 2005). Given the limited nature of this data set we cannot draw any firm conclusions regarding the offshore source of bromoform to Cape Point. However, this is still an interesting aspect of the region that will be monitored carefully in future work. 

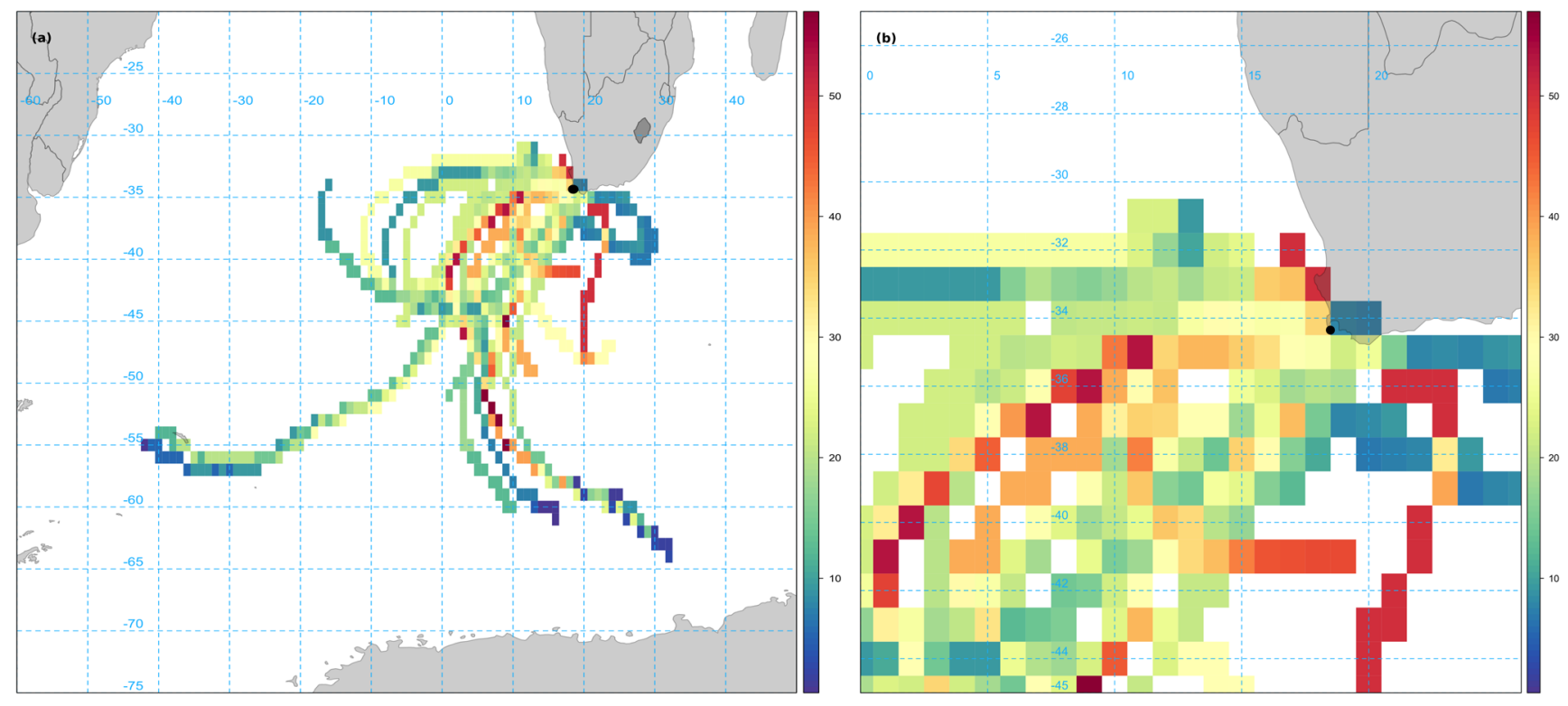

Figure 5. Smoothed CWT calculation of bromoform based on Hysplit back trajectories. (a) Zoomed to show full extent of $96 \mathrm{~h}$ back trajectories. (b) Zoomed to focus on Cape Point. Units in colour bar reflect bromoform mixing ratios measured at Cape Point.

\section{Conclusions}

The data presented here represent the first fixed-point quantitative atmospheric bromoform measurements at the Cape Point Global Atmospheric Watch Station but also the first such data set in southern Africa. The 135 discrete measurements made over the course of October/November 2011 exhibited a mean bromoform mixing ratio of $24.8 \pm 14.8 \mathrm{ppt}$. The maximum bromoform mixing ratio reported here (64.6 ppt) was consistent with past studies, for example that reported in Cape Verde (43.7 ppt, O'Brien et al., 2009) or New Hampshire (47.4 ppt, Zhou et al., 2008). However, it should be noted that the random errors in these measurements are quite large, with a precision of $22.2 \%$. The scale of these uncertainties is due to the manual nature of the system, trapping to injection, and oven temperature profile adjustments. Although the uncertainty associated with the data presented here is large, we feel that the data are still interesting as a first approximation of the range of values found in this region. Given the uncertainty, the data should be treated with a degree of caution.

The majority of measurements $(68 \%)$ were made in clean marine air $\left({ }^{222} \mathrm{Rn}\right)$, implying that for these measurements the bromoform being sampled was entirely biogenic. From the data presented here it appears that the most likely source of this bromoform is production from local kelp. Most of the periods in which bromoform concentrations were elevated for a prolonged time occurred around low tide, where kelp are exposed and most likely to produce bromoform as a response to oxidative stress. However, occasional intrusions of anthropogenically modified air may have contributed to the bromoform loading at Cape Point.

In a similar manner to the marshes surrounding Mace Head, it is possible that the fynbos vegetation at Cape Point may be a local source of bromoform to the north. The fynbos as a local source remains speculative at this stage but will be examined going forward.

The mean diurnal pattern appears to exhibit a similar pattern to, and fall within the range of, previously published reports. An increase in the mixing ratio was observed through the morning, returning to low concentrations throughout the rest of the day. A second maximum in the mean mixing ratios was observed in the early evening. Changes in the MBL height through the day are the most likely source of variation in bromoform mixing ratios in the diurnal cycle at Cape Point.

Back trajectory analysis using the CWT model from the openair package provides compelling evidence to suggest an offshore biogenic source. The main region of the source appears to be centred on the Agulhas current retroflection area. A second region of elevated bromoform mixing ratios appears to exist as a transect line extending from St Helena Bay southwest off South Africa. These will be monitored carefully going forward.

Given the relatively high concentrations reported, these data indicate that this under-sampled region, may be particularly significant in terms of bromoform sources to the atmosphere. Further work needs to be done to categorize the source strength and halocarbon release from the local kelp sources. Additional measurements, both in time, space, and halocarbon species, will be required to attain a greater under- 
standing of specific local processes governing the variability in bromoform in this region. It is thus clear that future measurements of bromoform mixing ratios at Cape Point would make an important contribution to the field. Work is currently underway to develop a more extensive halocarbon data set at Cape Point using updated equipment and calibration protocols.

Data availability. Halocarabon data observed at the Cape Point WMO/GAW station during October/November 2011 have been submitted to the HalOcAt repository. The data can be accessed at https://halocat.geomar.de. The data are also available in the Supplement to this article. All other data reported in this paper come from the South African Weather Service. Access can be granted by the paper's authors and data owners.

Supplement. The supplement related to this article is available online at: https://doi.org/10.5194/acp-18-5785-2018-supplement.

Author contributions. BK, CJP, and CJCR designed the experiments. BK measured the samples of bromoform, performed the analysis, wrote most of the manuscript, and created all the figures. CL measured the meteorological and ancillary data. CJP, CL, and BK performed the analysis. All authors contributed to reviewing and improving the text.

Competing interests. The authors declare that they have no conflict of interest.

Acknowledgements. Funding for the development of the system was generously provided through the START Foundation. The authors would like to thank Ernst Brunke of the South African Weather Service for his invaluable advice and support. The authors would like to thank Mike Davies-Coleman and Dudley Shallcross for their comments and suggestions, which greatly improved the quality of the text.

Edited by: Andreas Hofzumahaus

Reviewed by: two anonymous referees

\section{References}

Abrahamsson, K., Lorén, A., Wulff, A., and Wängberg, S. Å.: Airsea exchange of halocarbons: The influence of diurnal and regional variations and distribution of pigments, Deep-Sea Res. Pt II, 51, 2789-2805, https://doi.org/10.1016/j.dsr2.2004.09.005, 2004.

Allonier, A. S., Khalanski, M., Camel, V., and Bermond, A.: Characterization of chlorination by-products in cooling effluents of coastal nuclear power stations, Mar. Pollut. Bull., 38, 1232-1241, https://doi.org/10.1016/S0025-326X(99)00168-X, 1999.
Anderson, R., Rand, A., Rothman, M., Share, A., and Bolton, J.: Mapping and quantifying the South African kelp resource, Afr. J. Mar. Sci., 29, 369-378, https://doi.org/10.2989/AJMS.2007.29.3.5.335, 2007.

Arrigo, K. R., Perovich, D. K., Pickart, R. S., Brown, Z. W., Dijken, G. L. V., Lowry, K. E., Mills, M. M., Palmer, M. A., Balch, W. M., Bahr, F., Bates, N. R., Benitez-nelson, C., Bowler, B., Brownlee, E., Ehn, J. K., Frey, K. E., Garley, R., Laney, S. R., Lubelczyk, L., Mathis, J., Matsuoka, A., Mitchell, B. G., Moore, G. W. K., Ortega-retuerta, E., Pal, S., Polashenski, C. M., Reynolds, R. A., Schieber, B., Sosik, H. M., Stephens, M., and Swift, J. H.: Under Arctic Sea Ice, Science, 336, 2012, https://doi.org/10.1126/science.1215065, 2012.

Aschmann, J., Sinnhuber, B.-M., Atlas, E. L., and Schauffler, S. M.: Modeling the transport of very short-lived substances into the tropical upper troposphere and lower stratosphere, Atmos. Chem. Phys., 9, 9237-9247, https://doi.org/10.5194/acp-9-92372009, 2009.

Beal, L. M., De Ruijter, W. P., Biastoch, A., Zahn, R., Cronin, M., Hermes, J., Lutjeharms, J., Quartly, G., Tozuka, T., Baker-Yeboah, S., Bornman, T., Cipollini, P., Dijkstra, H., Hall, I., Park, W., Peeters, F., Penven, P., Ridderinkhof, H., and Zinke, J.: On the role of the Agulhas system in ocean circulation and climate, Nature, 472, 429-436, https://doi.org/10.1038/nature09983, 2011.

Brunke, E. G. and Halliday, E. C.: Halocarbon measurements in the southern hemisphere since 1977, Atmos. Environ., 17, 823-826, https://doi.org/10.1016/0004-6981(83)90433-X, 1983.

Brunke, E. G., Labuschagne, C., Parker, B., Scheel, H. E., and Whittlestone, S.: Baseline air mass selection at Cape Point, South Africa: Application of ${ }^{222} \mathrm{Rn}$ and other filter criteria to $\mathrm{CO}_{2}$, Atmos. Environ., 38, 5693-5702, https://doi.org/10.1016/j.atmosenv.2004.04.024, 2004.

Carpenter, L. J. and Liss, P. S.: On temperate sources of bromoform and other reactive organic bromine gases, J. Geophys. Res., 105, 20539-20547, https://doi.org/10.1029/2000JD900242, 2000.

Carpenter, L. J., Sturges, W. T., Penkett, S. A., Liss, P. S., Alicke, B., Hebestreit, K., and Platt, U.: Short-lived alkyl iodides and bromides at Mace Head, Ireland: Links to biogenic sources and halogen oxide production, J. Geophys. Res., 104, 1679-1689, https://doi.org/10.1029/98jd02746, 1999.

Carslaw, D. C. and Ropkins, K.: Openair - An r package for air quality data analysis, Environmental Modelling and Software, 27-28, 52-61, https://doi.org/10.1016/j.envsoft.2011.09.008, 2012.

Collén, J., Ekdahl, A., Abrahamsson, K., and Pedersén, M.: The involvement of hydrogen peroxide in the production of volatile halogenated compounds by Meristiella gelidium, Phytochemistry, 36, 1197-1202, https://doi.org/10.1016/S00319422(00)89637-5, 1994.

Cox, M., Sturrock, G., and Fraser, P.: Regional sources of methyl chloride, chloroform and dichloromethane identified from AGAGE observations at Cape Grim, Tasmania, 1998-2000, J. Atmos. Chem., 45, 79-99, https://doi.org/10.1023/A:1024022320985, 2003.

Ekdahl, A., Pedersén, M., and Abrahamsson, K.: A study of the diurnal variation of biogenic volatile halocarbons, Mar. Chem., 63, 1-8, https://doi.org/10.1016/S0304-4203(98)00047-4, 1998. 
Fiehn, A., Quack, B., Hepach, H., Fuhlbrügge, S., Tegtmeier, S., Toohey, M., Atlas, E., and Krüger, K.: Delivery of halogenated very short-lived substances from the west Indian Ocean to the stratosphere during the Asian summer monsoon, Atmos. Chem. Phys., 17, 6723-6741, https://doi.org/10.5194/acp17-6723-2017, 2017.

Fleming, Z. L., Monks, P. S., and Manning, A. J.: Review: Untangling the influence of air-mass history in interpreting observed atmospheric composition, Atmos. Res., 104-105, 1-39, https://doi.org/10.1016/j.atmosres.2011.09.009, 2012.

Fuhlbrügge, S., Krüger, K., Quack, B., Atlas, E., Hepach, H., and Ziska, F.: Impact of the marine atmospheric boundary layer conditions on VSLS abundances in the eastern tropical and subtropical North Atlantic Ocean, Atmos. Chem. Phys., 13, 6345-6357, https://doi.org/10.5194/acp-13-6345-2013, 2013.

Fuhlbrügge, S., Quack, B., Atlas, E., Fiehn, A., Hepach, H., and Krüger, K.: Meteorological constraints on oceanic halocarbons above the Peruvian upwelling, Atmos. Chem. Phys., 16, 1220512217, https://doi.org/10.5194/acp-16-12205-2016, 2016a.

Fuhlbrügge, S., Quack, B., Tegtmeier, S., Atlas, E., Hepach, H., Shi, Q., Raimund, S., and Krüger, K.: The contribution of oceanic halocarbons to marine and free tropospheric air over the tropical West Pacific, Atmos. Chem. Phys., 16, 7569-7585, https://doi.org/10.5194/acp-16-7569-2016, 2016b.

Groszko, W. and Moore, R. M.: Semipermeable membrane equilibrator for halomethanes in seawater, Chemosphere, 36, 30833092, https://doi.org/10.1016/S0045-6535(98)00019-8, 1998.

Gschwend, P. M., Macfarlane, J. K., and Newman, K. A.: Volatile Halogenated Organic Compounds Released to Seawater from Temperate Marine Macroalgae Published, Science, 227, 10331035, https://doi.org/10.1126/science.227.4690.1033, 1985.

Hossaini, R., Chipperfield, M. P., Monge-Sanz, B. M., Richards, N. A. D., Atlas, E., and Blake, D. R.: Bromoform and dibromomethane in the tropics: a 3-D model study of chemistry and transport, Atmos. Chem. Phys., 10, 719-735, https://doi.org/10.5194/acp-10-719-2010, 2010.

Hsu, Y. K., Holsen, T. M., and Hopke, P. K.: Comparison of hybrid receptor models to locate PCB sources in Chicago, Atmos. Environ., 37, 545-562, https://doi.org/10.1016/S13522310(02)00886-5, 2003.

Itoh, N., Tsujita, M., Ando, T., Hisatomi, G., and Higashi, T.: Formation and emission of monohalomethanes from marine algae, Phytochemistry, 45, 67-73, https://doi.org/10.1016/S00319422(96)00786-8, 1997.

Jennings, S., Kaiser, M., and Reynolds, J.: Marine Fisheries Ecology, Blackwell Scientific Publishers, 2001.

Jones, C. E. and Carpenter, L. J.: Solar Photolysis of $\backslash$ chem $\left\{\mathrm{CH} \_2 \mathrm{I} \_2\right\}, \backslash \operatorname{chem}\left\{\mathrm{CH} \_2 \mathrm{ICl}\right\}$, and $\backslash$ chem $\left\{\mathrm{CH} \_2 \mathrm{IBr}\right\}$ in Water, Saltwater, and Seawater, Environ. Sci. Technol., 39, 6130-6137, 2005.

Kudela, R., Pitcher, G., Probyn, T., Figuieras, F., Moita, T., and Trainer, V.: Harmful algal blooms in coastal upwelling systems, Oceanography, 18, 184-197, https://doi.org/10.5670/oceanog.2005.53, 2005.

Kupper, F. C., Carpenter, L. J., McFiggans, G. B., Palmer, C. J., Waite, T. J., Boneberg, E.-M. E.-M., Woitsch, S., Weiller, M., Abela, R., Grolimund, D., Potin, P., Butler, A., Luther, G. W., Kroneck, P. M. H., Meyer-Klaucke, W., Feiters, M. C., Küpper, F. C., Carpenter, L. J., McFiggans, G. B., Palmer, C. J., Waite,
T. J., Boneberg, E.-M. E.-M., Woitsch, S., Weiller, M., Abela, R., Grolimund, D., Potin, P., Butler, A., Luther, G. W., Kroneck, P. M. H., Meyer-Klaucke, W., Feiters, M. C., and Feiters, M. C.: Iodide accumulation provides kelp with an inorganic antioxidant impacting atmospheric chemistry, P. Natl. Acad. Sci. USA, 105, 6954-6958, https://doi.org/10.1073/pnas.0709959105, 2008.

Kuyper, B.: An investigation into the source and distribution of bromoform in the southern African and Southern Ocean marine boundary, Ph.D. thesis, University of Cape Tonw, Cape Town, 2014.

Kuyper, B., Labuschagne, C., Philibert, R., Moyo, N., Waldron, H., Reason, C., and Palmer, C. J.: Development of a simplified, cost effective GC-ECD methodology for the sensitive detection of bromoform in the troposphere, Sensors, 12, 13583-13597, https://doi.org/10.3390/s121013583, 2012.

Liss, P. S. and Merlivat, L.: The Role of Air-Sea Exchange in Geochemical Cycling, D. Reidel Publishing Company, 1986.

Manley, S. L., Goodwin, K., and North, W. J.: Laboratory production of bromoform, methylene bromide, and methyl iodide by macroalgae and distribution in nearshore southern California waters, Limnol. Oceanogr., 37, 1652-1659, https://doi.org/10.4319/lo.1992.37.8.1652, 1992.

Mattsson, E., Karlsson, A., and Abrahamsson, K.: Regional sinks of bromoform in the Southern Ocean, Geophys. Res. Lett., 40, 3991-3996, https://doi.org/10.1002/grl.50783, 2013.

Mohd Nadzir, M. S., Phang, S. M., Abas, M. R., Abdul Rahman, N., Abu Samah, A., Sturges, W. T., Oram, D. E., Mills, G. P., Leedham, E. C., Pyle, J. A., Harris, N. R. P., Robinson, A. D., Ashfold, M. J., Mead, M. I., Latif, M. T., Khan, M. F., Amiruddin, A. M., Banan, N., and Hanafiah, M. M.: Bromocarbons in the tropical coastal and open ocean atmosphere during the 2009 Prime Expedition Scientific Cruise (PESC-09), Atmos. Chem. Phys., 14, 8137-8148, https://doi.org/10.5194/acp-14-8137-2014, 2014.

Moore, R. M., Groszko, W., and Niven, S. J.: Ocean-atmosphere exchange of methyl chloride: Results from NW Atlantic and Pacific Ocean studies, J. Geophys. Res., 101, 28529-28538, 1996.

Nightingale, P. D., Malin, G., and Liss, P. S.: Production of chloroform and other low-molecular-weight halocarbons by some species of macroalgae, Limnol. Oceanogr., 40, 680-689, https://doi.org/10.4319/lo.1995.40.4.0680, 1995.

Nightingale, P. D., Malin, G., Law, C. S., Watson, A. J., Liss, P. S., Liddicoat, M. I., Boutin, J., and Upstill-Goddard, R. C.: In situ evaluation of air-sea gas exchange parametrizations using novel conservsative and volatile tracers, Global Biogeochem. Cy., 14, 373-387, 2000.

O’Brien, L. M., Harris, N. R. P., Robinson, A. D., Gostlow, B., Warwick, N., Yang, X., and Pyle, J. A.: Bromocarbons in the tropical marine boundary layer at the Cape Verde Observatory - measurements and modelling, Atmos. Chem. Phys., 9, 9083-9099, https://doi.org/10.5194/acp-9-9083-2009, 2009.

Palmer, C. J. and Reason, C. J.: Relationships of surface bromoform concentrations with mixed layer depth and salinity in the tropical oceans, Global Biogeochem. Cy., 23, 1-10, https://doi.org/10.1029/2008GB003338, 2009.

Palmer, C. J., Anders, T. L., Carpenter, L. J., Küpper, F. C., and McFiggans, G. B.: Iodine and halocarbon response of laminaria digitata to oxidative stress and links to atmospheric new particle production, Environ. Chem., 2, 282-290, https://doi.org/10.1071/EN05078, 2005. 
Paul, C. and Pohnert, G.: Production and role of volatile halogenated compounds from marine algae, Nat. Prod. Rep., 28, 186195, https://doi.org/10.1039/c0np00043d, 2011.

Pedersén, M., Collen, J., Abrahamsson, K., and Ekdahl, A.: Production of halocarbons from seaweeds: an oxidative stress reaction, 1996.

Pekney, N., Davidson, C., Zhou, L., and Hopke, P.: Application of PSCF and CPF to PMF-modeled sources of PM2.5 in Pittsburgh, Aerosol Sci. Technol., 40, 952-961, https://doi.org/10.1080/02786820500543324, 2006.

Poole, C.: The Essence of Chromatography, Elsevier Ltd., 2003.

Pyle, J. A., Ashfold, M. J., Harris, N. R. P., Robinson, A. D., Warwick, N. J., Carver, G. D., Gostlow, B., O’Brien, L. M., Manning, A. J., Phang, S. M., Yong, S. E., Leong, K. P., Ung, E. H., and Ong, S.: Bromoform in the tropical boundary layer of the Maritime Continent during OP3, Atmos. Chem. Phys., 11, 529-542, https://doi.org/10.5194/acp-11-529-2011, 2011.

Quack, B. and Suess, E.: Volatile halogenated hydrocarbons over the western Pacific between $43^{\wedge}\{\backslash$ circ $\}$ and $4^{\wedge}\{\backslash$ circ $\} \sim N$, J. Geophys. Res., 104, 1663-1678, 1999.

Quack, B. and Wallace, D. W. R.: Air-sea flux of bromoform: Controls, rates, and implications, Global Biogeochem. Cy., 17, 1023, https://doi.org/10.1029/2002GB001890, 2003.

Quack, B., Atlas, E., Petrick, G., Stroud, V., Schauffler, S., and Wallace, D. W.: Oceanic bromoform sources for the tropical atmosphere, Geophys. Res. Lett., 31, 1-4, https://doi.org/10.1029/2004GL020597, 2004.

Quack, B., Atlas, E., Petrick, G., and Wallace, D. W. R.: Bromoform and dibromomethane above the Mauritanian upwelling: Atmospheric distributions and oceanic emissions, J. Geophys. Res.-Atmos., 112, 1-9, https://doi.org/10.1029/2006JD007614, 2007a.

Quack, B., Peeken, I., Petrick, G., and Nachtigall, K.: Oceanic distribution and sources of bromoform and dibromomethane in the Mauritanian upwelling, J. Geophys. Res.-Oceans, 112, C10006, https://doi.org/10.1029/2006JC003803, 2007b.

Redeker, K. R., Meinardi, S., Blake, D., and Sass, R.: Gaseous emissions from flooded rice paddy agriculture, J. Geophys. Res., 108, 4386, https://doi.org/10.1029/2002JD002814, 2003.

Saiz-Lopez, A., Lamarque, J.-F., Kinnison, D. E., Tilmes, S., Ordóñez, C., Orlando, J. J., Conley, A. J., Plane, J. M. C., Mahajan, A. S., Sousa Santos, G., Atlas, E. L., Blake, D. R., Sander, S. P., Schauffler, S., Thompson, A. M., and Brasseur, G.: Estimating the climate significance of halogen-driven ozone loss in the tropical marine troposphere, Atmos. Chem. Phys., 12, 3939-3949, https://doi.org/10.5194/acp-12-3939-2012, 2012.

Sala, S., Bönisch, H., Keber, T., Oram, D. E., Mills, G., and Engel, A.: Deriving an atmospheric budget of total organic bromine using airborne in situ measurements from the western Pacific area during SHIVA, Atmos. Chem. Phys., 14, 6903-6923, https://doi.org/10.5194/acp-14-6903-2014, 2014.

Seibert, P., Beyrich, F., Gryning, S.-E., Joffre, S., Rasmussen, A., and Tercier, P.: Review and intercomparison of operational methods for the determination of the mixing height, Atmos. Environ., 34, 1001-1027, https://doi.org/10.1016/S1352-2310(99)003490,2000

Seidel, D. J., Ao, C. O., and Li, K.: Estimating climatological planetary boundary layer heights from radiosonde observations: Comparison of methods and uncertainty analysis, J. Geophys.
Res.-Atmos., 115, 1-15, https://doi.org/10.1029/2009JD013680, 2010.

Stein, A. F., Draxler, R. R., Rolph, G. D., Stunder, B. J. B., Cohen, M. D., and Ngan, F.: Noaa's hysplit atmospheric transport and dispersion modeling system, B. Am. Meteorol. Soc., 96, 20592077, https://doi.org/10.1175/BAMS-D-14-00110.1, 2015.

Tokarczyk, R. and Moore, R. M.: Production of volatile organohalogens by phytoplankton cultures, Geophys. Res. Lett., 21, 285288, https://doi.org/10.1029/94GL00009, 1994.

Tyson, P. and Preston-Whyte, R.: The Weather and Climate of Southern Africa, Oxford University Press, 2000.

Underhill, L. G. and Bradfield, D.: Introstat, Juta Academic, Cape Town, South Africa, 2005.

Wanninkhof, R. H.: Relationship between wind speed and gas exchange, J. Geophys. Res., 97, 7373-7382, https://doi.org/10.1029/92JC00188, 1992.

Warwick, N. J., Pyle, J. A., Carver, G. D., Yang, X., Savage, N. H., O'Connor, F. M., and Cox, R. A.: Global modeling of biogenic bromocarbons, J. Geophys. Res.-Atmos., 111, 1-12, https://doi.org/10.1029/2006JD007264, 2006.

Wevill, D. J. and Carpenter, L. J.: Automated measurement and calibration of reactive volatile halogenated organic compounds in the atmosphere, Analyst, 129, 634-638, https://doi.org/10.1039/b403550j, 2004.

Whittlestone, S. and Zahorowski, W.: Baseline radon detectors for shipboard use: Development and deployment in the First Aerosol Characterisation Experiment (ACE 1), J. Geophys. Res., 103, 16743-16751, 1998.

Whittlestone, S., Kowalczyk, E., Brunke, E. G., and Labuschagne, C.: Source regions for $\mathrm{CO}_{2}$ at Cape Point assessed by modelling, ${ }^{222} \mathrm{Rn}$ and meteorological data, Tech. rep., South African Weather Service, Pretoria, South Africa, 2009.

Yokouchi, Y., Inagaki, T., Yazawa, K., Tamaru, T., Enomoto, T., and Izumi, K.: Estimates of ratios of anthropogenic halocarbon emissions from Japan based on aircraft monitoring over Sagami Bay, Japan, J. Geophys. Res.-Atmos., 110, 1-7, https://doi.org/10.1029/2004JD005320, 2005.

Yokouchi, Y., Saito, T., Zeng, J., Mukai, H., and Montzka, S.: Seasonal variation of bromocarbons at Hateruma Island, Japan: implications for global sources, J. Atmos. Chem., 74, 171-185, https://doi.org/10.1007/s10874-016-9333-9, 2017.

Zhou, Y., Mao, H., Russo, R. S., Blake, D. R., Wingenter, O. W., Haase, K. B., Ambrose, J., Varner, R. K., Talbot, R., and Sive, B. C.: Bromoform and dibromomethane measurements in the seacoast region of New Hampshire, 2002-2004, J. Geophys. Res.-Atmos., 113, 2002-2004, https://doi.org/10.1029/2007JD009103, 2008.

Ziska, F., Quack, B., Abrahamsson, K., Archer, S. D., Atlas, E., Bell, T., Butler, J. H., Carpenter, L. J., Jones, C. E., Harris, N. R. P., Hepach, H., Heumann, K. G., Hughes, C., Kuss, J., Krüger, K., Liss, P., Moore, R. M., Orlikowska, A., Raimund, S., Reeves, C. E., Reifenhäuser, W., Robinson, A. D., Schall, C., Tanhua, T., Tegtmeier, S., Turner, S., Wang, L., Wallace, D., Williams, J., Yamamoto, H., Yvon-Lewis, S., and Yokouchi, Y.: Global sea-to-air flux climatology for bromoform, dibromomethane and methyl iodide, Atmos. Chem. Phys., 13, 89158934, https://doi.org/10.5194/acp-13-8915-2013, 2013. 